\title{
A FURTHER LATIN INSCRIPTION AND AN AMPHORA IN CAPE TOWN ${ }^{1}$
}

\section{B Saddington (University of the Witwatersrand)}

In a former volume of this journal I described a Latin inscription in the Cape Town Museum (Akroterion XLVI [2001] 99f.).

On a subsequent visit to the city, I went to the Wine Museum on the Groot Constantia estate. ${ }^{2}$ I was interested to find two Roman objects there, an inscription and an amphora.

The inscription is on a framed rectangular slab of white marble with a two-handled bowlshaped cavity in the middle. In the centre of the cavity there is a hole. The slab had presumably been placed above a receptacle containing the ashes of the deceased. The Romans were in the habit of visiting the tombs of their dead and making offerings to them. The central hole may have been intended as a passage for some of these to reach the deceased (see Figure 1).

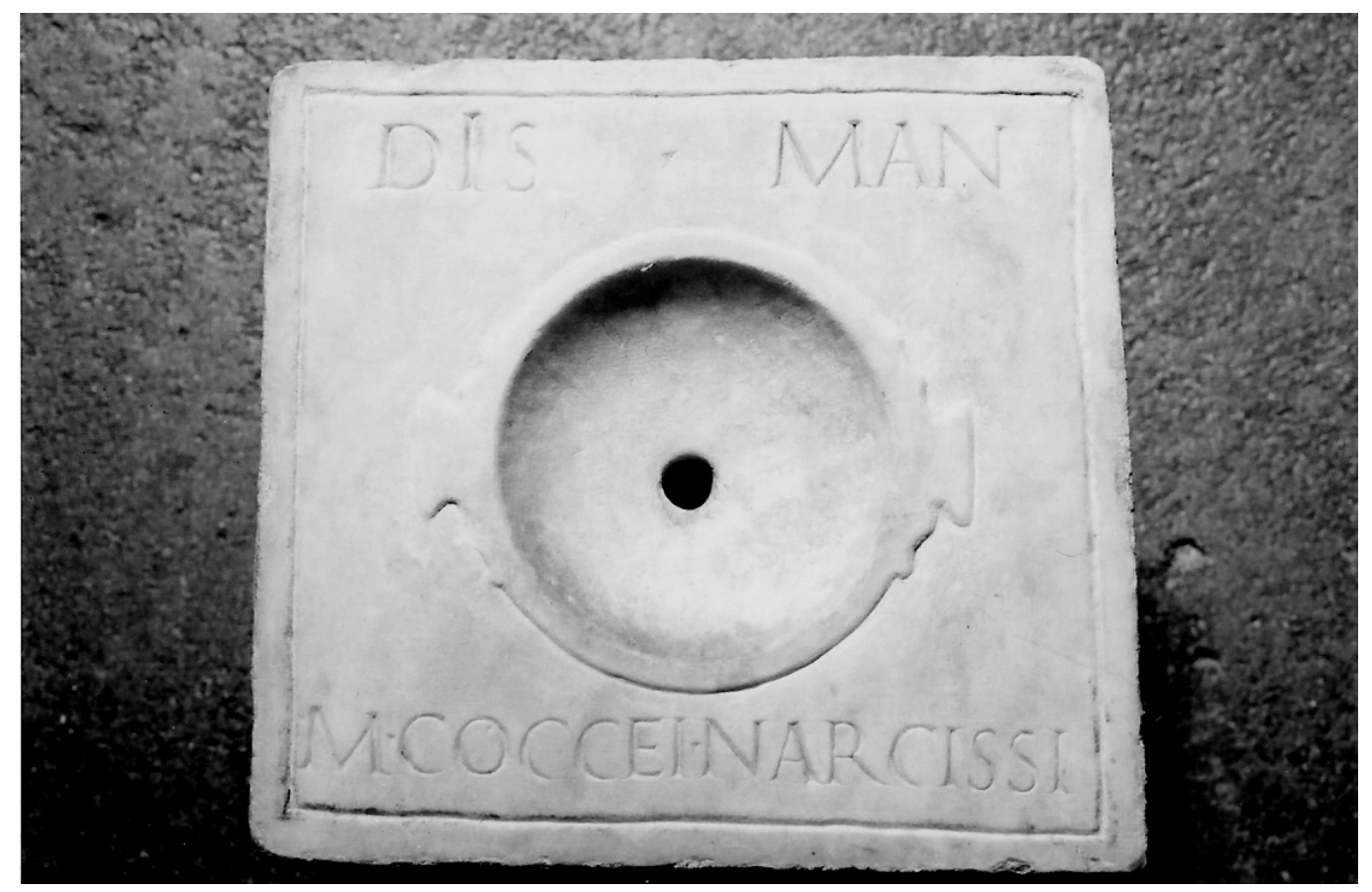

Fig. 1: Tablet SACHM 71/200 (Iziko Museums of Cape Town).

The inscription reads

DIS $\forall$ MAN

$\mathrm{M} \forall$ COCCEI $\forall$ NARCISSI

i.e., "Dis Manibus Marci Cocceii Narcissi", "To the departed spirits of M. Cocceius Narcissus".

1. I should like to thank Dr Hanel of the Department of Archaeology in the University of Cologne for his kind assistance on various points.

2. These items are the property of the Iziko Museums of Cape Town. I wish to thank Ms A Boshoff of the Museums for her generous help in providing information about them. 
The first part of his name is Latin, the last "Greek". Narcissus was a common Greek name, the most famous bearer of which was the powerful freedman of the Emperor Claudius, his Secretary for Correspondence, whose "household" is mentioned by Paul (Rom. 16, 11).

However, this Narcissus is to be dated half a century later. The first part of his name comes from that of the emperor M. Cocceius Nerva who ruled the Roman world from AD 96 to 98 between Domitian and Trajan. M. Cocceius Narcissus was in all likelihood a slave freed by him (or a descendant of a slave freed by him). (For such imperial freedmen, cf. my earlier note cited above.)

In the Iziko Museum, the inscription is classified as Tablet SACHM 71/200. The Museum description states, "It was found outside the Porta Pinciana, Rome, in 1726 and comes from the Lowther Castle Collection, Westmoreland, UK." The Museum purchased it in 1971.

It is in fact recorded in Volume VI (the "Rome" volume) of the Corpus Inscriptionum Latinarum as no. 15906a.

The amphora in the Museum catalogue (AMPHORA C 70/1) is described as follows: "long slim neck with a well-marked point of departure from the shoulders; wide upright collar rim; handles almost straight and parallel to the neck; joined to the neck just below the rim; belly almost parallel-sided for about two-thirds of the distance down from the shoulders; fairly long base terminating in flat spike. Stamped on base: inverted pyramid [unidentified mark]" (see Figure 2).
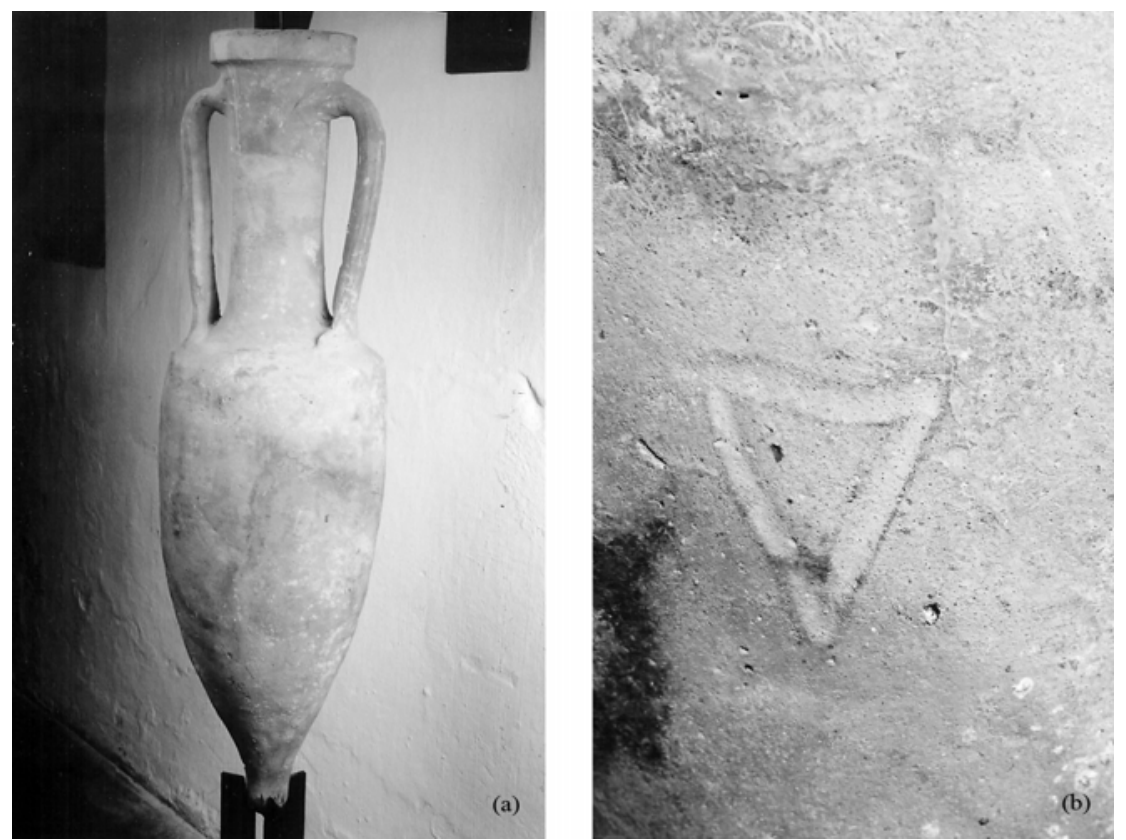

Fig. 2: (a) Amphora C 70/1 and (b) Inverted pyramid on amphora (Iziko Museums of Cape Town).

Amphorae were multi-purpose vessels in the Roman world, used especially for transporting wine, olive oil and other agricultural products. This example was made from white clay in sections built up from the bottom. The potter's mark, probably incised by a finger, was made before firing. It resembles the Greek letter $\Delta$ (delta), but there appear to be no parallels to it. 